\title{
Selected Properties of Formaldehyde-Free Polymer-Straw Boards Made from Different Types of Thermoplastics and Different Kinds of Straw
}

\author{
Radosław Mirski ${ }^{1, *(D)}$, Aleksandra Banaszak ${ }^{1}$ and Pavlo Bekhta ${ }^{2}(D)$ \\ 1 Department of Wood-Based Materials, Poznań University of Life Sciences, 60-627 Poznań, Poland; \\ banaszak@up.poznan.pl \\ 2 Department of Wood-Based Composites, Cellulose, and Paper, Ukrainian National Forestry University, \\ 79057 Lviv, Ukraine; bekhta@nltu.edu.ua \\ * Correspondence: rmirski@up.poznan.pl; Tel.: +48-061-848-7616
}

check for

updates

Citation: Mirski, R.; Banaszak, A.; Bekhta, P. Selected Properties of Formaldehyde-Free Polymer-Straw Boards Made from Different Types of Thermoplastics and Different Kinds of Straw. Materials 2021, 14, 1216. https://doi.org/10.3390/ ma14051216

Academic Editor:

Arunas Ramanavicius

Received: 23 January 2021

Accepted: 26 February 2021

Published: 4 March 2021

Publisher's Note: MDPI stays neutral with regard to jurisdictional claims in published maps and institutional affiliations.

Copyright: (c) 2021 by the authors. Licensee MDPI, Basel, Switzerland. This article is an open access article distributed under the terms and conditions of the Creative Commons Attribution (CC BY) license (https:// creativecommons.org/licenses/by/ $4.0 /)$.

\begin{abstract}
This research investigated the effects of different thermoplastics types and different kinds of straw on selected properties of polymer-straw boards. Polyethylene, polyethylene, and polystyrene of virgin and of recycled origin were used for bonding the boards. Three kinds of straw were used: rape (Brassica napus L. var. napus), triticale (Triticosecale Witt $\mathrm{b}$ m.), and rye (Secale L.). Five-layer polymer-straw boards were produced. The obtained boards differed in both the materials they were made of and the moisture content $(7,25$, and $2 \%$ for the core, the middle, and the face layers, respectively), and $30 \%$ of straw particles were substituted with thermoplastics added to the face layers. It was found that properties of polymer-straw boards strongly depend on both the kind of straw and the type of polymer used. The best mechanical properties were obtained for rye straw and polystyrene or recycled polymers, whereas the best hydrophobic properties were observed for rape straw combined with recycled polyethylene or polypropylene. Although recycled polymers improved the hydrophobic properties of the boards, they impaired their mechanical properties in comparison with the reference ones. However, in terms of bending strength, they still met the requirements for heavy duty load-bearing boards for use in humid conditions (20 MPa for P7 boards according to EN 312).
\end{abstract}

Keywords: polymer-straw boards; thermoplastic polymers; straw; hydrophobicity; mechanical properties

\section{Introduction}

Wood-based materials, especially particleboards, have been greatly popular for many years. The quality of technological lines, excluding those requiring chips of specific type, e.g., OSB (oriented strand board) [1-6], enables processing of practically any type of wood into particleboards. Wood generated as waste from sawmill production processes [7-9], from forest fires [10], post-consumer or recycled wood, or fine and undersize chips [11-18] are easily used in these processes. This ease of the use of wood material even of low quality does not hinder a search for alternate materials for production of furniture or construction boards. Therefore, works on the possible use of straw from various cereal species for production of particleboards [19-30] or even boards as demanding as OSB [31-33] are continued. Particles from these straws can partly substitute wood chips or be used as a homogeneous component of manufactured boards. Wheat, rye, rice, or even maize straws are used most commonly. These materials represent an attractive substitute for wood due to a range of useful properties of products, of which they are a main component. For example, they provide better hygroscopicity, better thermal [34] and acoustic [35] insulation, and lower [36] specific weight, and they are much cheaper than wood. Attempts to use straw in particleboards were already made in the 1960s; however the problem of worse gluing of straw particles, when compared with wood, was hard to overcome. Problems with 
gluing, as well other issues related to urea-formaldehyde (UF) or phenol-formaldehyde (PF) resins, can be solved by using pMDI (polymeric diphenylmethane diisocyanate) adhesive [32,37-39]. Straw particles glued with pMDI adhesive and formed into mediumor high-density boards can be successfully used in furniture or construction sectors. In this second industry, these boards can be used for structural applications $[30,33,39,40]$. However, the company VestaEco uses straw particles glued with pMDI in its technology for production of insulation materials [41].

Particles obtained from straw were also successfully used as a filler for manufacturing of wood plastic composites (WPC) [42,43]. WPCs are commonly manufactured from meal, sawdust, or fine chips by various ways, such as compression molding, extrusion, or injection [44]. These methods ensure better mixing of components, but require much finer fractions of lignocellulosic fillers. The use of methods commonly used for production of wood-based materials offers some solutions to this problem [45-53]. In this case, layers of lignocellulosic and thermoplastic materials can be formed alternately or thermoplastic material with particles of a size similar to plant particles can be used [53-56]. Typical thermoplastic materials for WPC production include polypropylene, polyethylene, polystyrene, or polyvinyl chloride.

Their advantage is a possibility of their reuse for production of the same or other products. In both cases, products of standard quality are obtained. These materials should be recovered when they become a municipal waste. In the European Union, basic rules and definitions concerning waste management are specified in the Waste Framework Directive [57]. Recovered plastics usually undergo mechanical recycling. However, thermoplastic waste can undergo either material or energy recycling. The energy recycling through incineration can always be the last stage in the cycle of the product life. About 6.3 billion tons of waste plastics are fabricated each year all over the world, while only a slight part of them $(\sim 9 \%)$ are recycled. Consequently the majority of them $(\sim 79 \%)$ are accumulated in the environment. [58]. Although it may appear strange, the demand for recycled plastics in Europe represents ca. $6 \%$ of the total demand for plastic materials. Therefore, it seems that, with overproduction of straw (it is estimated that, in the UK alone, as much as 4 million tonnes of straw are wasted every year), a direction enabling combining these two materials into a product of advantageous physical and mechanical properties is a correct one for the coming years.

Thus, the presented study aimed to combine wastes of straw and thermoplastics into polymer-straw board and to determine the effect of a kind of straw and a type of thermoplastics on both mechanical and physical properties of manufactured polymerstraw boards.

\section{Materials and Methods}

\subsection{Materials}

Rye (Ys), triticale (Ts), and rape (Rs) straws were used in the study. The straw was obtained in an unshredded form and then shredded in a laboratory mill. An attempt was made to obtain chopped straw of a length similar to pine chips $(\mathrm{Pw})$ used in the middle layer in particleboard production. Particles obtained by shredding were additionally sieved on a screen with $0.5 \times 0.5 \mathrm{~mm}^{2}$ mesh, to remove very fine and dust fractions. Samples for size and bulk density determinations were collected from prepared batches of the material. Linear dimensions of particles obtained this way are shown in Table 1. A detailed description is provided in publication [29]. Data included in Table 1 shows that obtained particles differ mainly in their thickness. This parameter is difficult to influence during the shredding process. Thickness of grass stalks is much lower than that of rape straw, and this translates into a lower thickness of obtained particles. The linear dimensions influence bulk density of obtained fractions. In this case, fractions for board manufacturing produced by shredding rye and triticale straws had similar bulk density of $60 \mathrm{~kg} / \mathrm{m}^{3}$, while bulk density of fractions obtained from rape straw was $80 \mathrm{~kg} / \mathrm{m}^{3}$. Bulk density of pine chips was over twice as high as that of cereal chips. 
Table 1. Linear dimensions and bulk density of straw and wood particles used in the study.

\begin{tabular}{cccccc}
\hline Material & & \multicolumn{4}{c}{ Properties of Particles } \\
\cline { 3 - 6 } & Symbol & $\begin{array}{c}\text { Length } \\
(\mathbf{m m})\end{array}$ & $\begin{array}{c}\text { Width } \\
(\mathbf{m m})\end{array}$ & $\begin{array}{c}\text { Thickness } \\
\mathbf{( m m})\end{array}$ & $\begin{array}{c}\text { Bulk Density } \\
\left(\mathbf{k g} / \mathbf{m} \mathbf{m}^{\mathbf{m}}\right.\end{array}$ \\
\hline $\begin{array}{c}\text { Rape straw } \\
\text { (Brassica napus L. var. napus) }\end{array}$ & Rs & $14.06 \pm 9.8$ & $2.18 \pm 1.08$ & $0.62 \pm 0.43$ & $80 \pm 2.0$ \\
\hline $\begin{array}{c}\text { Triticale straw } \\
\text { (Triticosecale Witt b m.) }\end{array}$ & Ts & $18.26 \pm 12.5$ & $2.55 \pm 1.25$ & $0.30 \pm 0.25$ & $60 \pm 1.2$ \\
\hline Rye straw (Secale L.) & Ys & $16.81 \pm 11.6$ & $1.70 \pm 0.79$ & $0.25 \pm 0.17$ & $60 \pm 2.3$ \\
\hline Pine wood particles (Pinus sylvestris L.) & Pw & $13.72 \pm 11.1$ & $2.03 \pm 1.10$ & $1.04 \pm 0.52$ & $130 \pm 1.9$ \\
\hline
\end{tabular}

The following thermoplastic materials, differing in types, forms, and softening point, were used in the study:

- PP-polypropylene,

- HDPE-high density polyethylene,

- LDPE-low density polyethylene,

- PS-polystyrene,

- LDPE rec. yellow-low density polyethylene from recycled scraps of yellow plastic,

- LDPE rec. pink-low density polyethylene from recycled scraps of pink plastic,

- $\quad$ PP recycled-polypropylene from reusable packaging.

In these studies, both native/virgin and recycled polymers were used. Their basic characteristics and appearance are presented in Table 2.

Table 2. Basic properties of the investigated thermoplastics.

\begin{tabular}{|c|c|c|c|c|}
\hline ThermoPlAstic Type & Density $\left[\mathrm{g} / \mathrm{cm}^{3}\right]$ & $\begin{array}{l}\text { Softening Point } \\
\text { [Vicata (A50)] }\end{array}$ & $\begin{array}{c}\text { MFR } \\
\text { (Melt Flow Index) }\end{array}$ & Photo \\
\hline PP & 0.9 & $150{ }^{\circ} \mathrm{C}$ & $\begin{array}{c}4 \mathrm{~g} / 10 \mathrm{~min} \\
\left(230^{\circ} \mathrm{C} / 2.16 \mathrm{~kg}\right)\end{array}$ & \\
\hline HDPE & 0.952 & $125^{\circ} \mathrm{C}$ & $\begin{array}{c}0.3 \mathrm{~g} / 10 \mathrm{~min} \\
\left(190^{\circ} \mathrm{C} / 2.16 \mathrm{~kg}\right)\end{array}$ & \\
\hline PS & 1.5 & $90{ }^{\circ} \mathrm{C}$ & $\begin{array}{c}6 \mathrm{~g} / \mathrm{min} \\
\left(200^{\circ} \mathrm{C} / 5 \mathrm{~kg}\right)\end{array}$ & \\
\hline LDPE & 0.923 & $91^{\circ} \mathrm{C}$ & $\begin{array}{c}1.5 \mathrm{~g} / 10 \mathrm{~min} \\
\left(190^{\circ} \mathrm{C} / 2.16 \mathrm{~kg}\right)\end{array}$ & \\
\hline PP_R & 0.54 * & $148^{\circ} \mathrm{C}$ & $\mathrm{Nd}$ & \\
\hline
\end{tabular}


Table 2. Cont.

\begin{tabular}{cccc}
\hline ThermoPlAstic Type & Density $\left[\mathrm{g} / \mathrm{cm}^{3}\right]$ & $\begin{array}{c}\text { Softening Point } \\
\text { [Vicata (A50)] }\end{array}$ & $\begin{array}{c}\text { MFR } \\
\text { (Melt Flow Index) }\end{array}$ \\
\hline LDPE_RZ & $0.37^{*}$ & $89{ }^{\circ} \mathrm{C}$ & $\mathrm{Nd}$ \\
\hline LDPE_RR & & & $\mathrm{Nd}$ \\
\hline
\end{tabular}

Note: *—bulk density; nd—not determined.

The polymers used in the study are commonly available, and their recycling is not problematic, as they can be reprocessed many times. However, new, alternate methods for their management are continuously sought. When they are combined with wood, the obtained material has better hydrophobic properties than wood. However, the use of adhesion promoters facilitates achieving better biding of wood and polymer. Isocyanate compounds can be used both as agents binding wood or straw particles with each other, and as adhesion promoters for systems composed of lignocellulosic material and thermoplastic polymer. Therefore, we decided to use a polymeric diphenylmethane diisocyanate adhesive (pMDI, Ongronat ${ }^{2} 2100$, BorsodChem Group, Kazincbarcika, Hungary) in our study. Ongronat ${ }^{\circledR} 2100$ is a brown $\left(20^{\circ} \mathrm{C}, 1013 \mathrm{hPa}\right)$ non-flammable liquid of a density $1.23 \mathrm{~g} / \mathrm{cm}^{3}$, viscosity of $210 \mathrm{mPa} \cdot \mathrm{s}$, contractual dry matter content of $100 \%$, NCO content of $30.6 \%$, and chlorine hydrolytic $127 \mathrm{mg} / \mathrm{kg}$.

\subsection{Manufacturing of Polymer-Straw Samples}

In the laboratory conditions, five-layer boards were produced, of the following shares of individual layers: $12.5 \%: 12.5 \%: 50 \%: 12.5 \%: 12.5 \%$. The individual layers varied in terms of the type of material and moisture content (Figure 1):

- face layers $(1,5)$ were made of straw of $2 \%$ moisture content, with $30 \%$ polymer addition,

- intermediate layers $(2,4)$ were made of straw of $25 \%$ moisture content,

- the core layer (3) was made of pine chips of $7 \%$ moisture content.

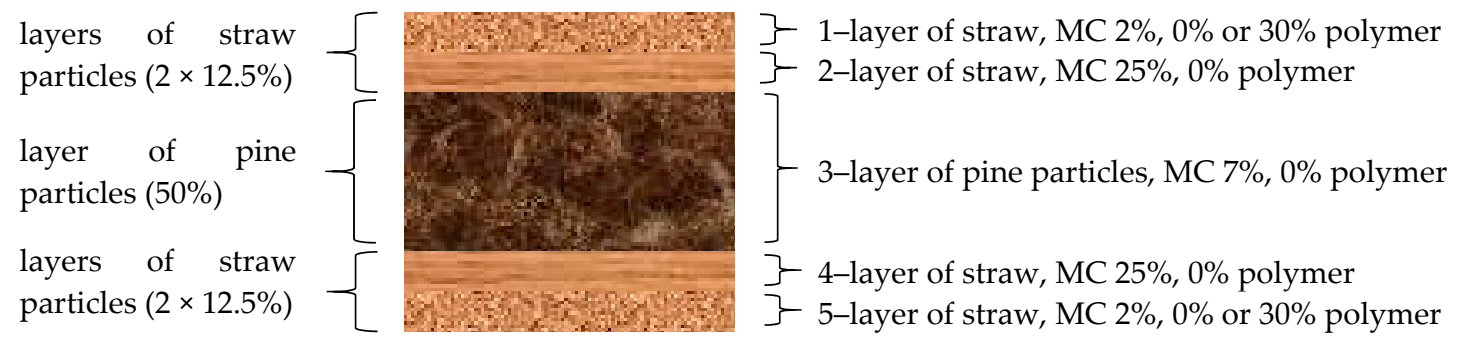

Figure 1. Structure of manufactured boards.

Our previous studies [59] indicate that it is advantageous to use lignocellulosic material of low moisture content, i.e., below $4 \%$, in manufacturing polymer containing products, and this observation is supported by other authors [60-62]. For this reason, the lignocellulosic material intended for face layers was dried to a level below $2 \%$. To accelerate the process of heat transfer into the board, intermediate layers were manufactured of material with $25 \%$ moisture content. It is consistent with a general practice of particleboard production [63-65]. Therefore, the boards produced without thermoplastics were evaluated prior to actual experiments. The following materials were prepared: 
- $\quad$ single-layer boards made only of pine chips with $7 \%$ moisture content;

- three-layer boards, with a core layer of pine chips and face layers of straw particles of moisture content of ca. $7 \%$;

- five-layer boards of the same structure as the boards with polymers.

Table 3 presents systems of the manufactured boards with symbols assigned.

Table 3. List of boards produced and symbols used.

\begin{tabular}{|c|c|c|c|c|c|c|c|c|}
\hline \multirow{3}{*}{$\begin{array}{l}\text { Board } \\
\text { Code }\end{array}$} & \multirow{3}{*}{$\begin{array}{l}\text { Number of } \\
\text { Board Layers }\end{array}$} & \multirow{3}{*}{ Polymer Type } & \multirow{3}{*}{$\begin{array}{l}\text { Kind of } \\
\text { Straw }\end{array}$} & \multicolumn{5}{|c|}{ Materials/Polymer Share (as \%) in Board Layers } \\
\hline & & & & \multicolumn{5}{|c|}{ Layer } \\
\hline & & & & 1 & 2 & 3 & 4 & 5 \\
\hline $\mathrm{Pw}$ & 1 & Without polymer & $\begin{array}{l}\text { Without } \\
\text { straw }\end{array}$ & \multicolumn{5}{|c|}{$\mathrm{Pw} / 0$; one-layer board } \\
\hline Rs-Pw & 3 & Without polymer & Rs & Rs/0 & - & Rs/0 & - & Rs/0 \\
\hline Ys-Pw & 3 & Without polymer & Ys & Ys/0 & - & Ys/0 & - & Ys/0 \\
\hline Rs-Pw-0 & 5 & Without polymer & Rs & Rs/0 & Rs $/ 0$ & $\mathrm{Pw} / 0$ & Rs $/ 0$ & Rs $/ 0$ \\
\hline Ys-Pw-0 & 5 & Without polymer & Ys & Ys/0 & $\mathrm{Ys} / 0$ & $\mathrm{Pw} / 0$ & Ys/0 & Ys/0 \\
\hline Ts-Pw-0 & 5 & Without polymer & Ts & $\mathrm{Ts} / 0$ & Ts $/ 0$ & $\mathrm{Pw} / 0$ & $\mathrm{Ts} / 0$ & $\mathrm{Ts} / 0$ \\
\hline Rs-Pw-PP & 5 & PP & Rs & Rs/30 & $\mathrm{R} / 0 \mathrm{~s}$ & $\mathrm{Pw} / 0$ & Rs $/ 0$ & $\mathrm{Rs} / 30$ \\
\hline Ys-Pw-PP & 5 & PP & Ys & Ys/30 & $\mathrm{Y} / 0 \mathrm{~s}$ & $\mathrm{Pw} / 0$ & $\mathrm{Ys} / 0$ & $\mathrm{Ys} / 30$ \\
\hline Ts-Pw-PP & 5 & $\mathrm{PP}$ & Ts & Ts $/ 30$ & Ts $/ 0$ & $\mathrm{Pw} / 0$ & $\mathrm{Ts} / 0$ & Ts $/ 30$ \\
\hline $\begin{array}{l}\text { Rs-Pw- } \\
\text { PP_R }\end{array}$ & 5 & PP_R & Rs & $\mathrm{Rs} / 30$ & $\mathrm{R} / 0 \mathrm{~s}$ & $\mathrm{Pw} / 0$ & Rs $/ 0$ & Rs $/ 30$ \\
\hline $\begin{array}{l}\text { Ys-Pw- } \\
\text { PP_R }\end{array}$ & 5 & PP_R & Ys & Ys/30 & $\mathrm{Y} / 0 \mathrm{~s}$ & $\mathrm{Pw} / 0$ & Ys/0 & $\mathrm{Ys} / 30$ \\
\hline $\begin{array}{l}\text { Ts-Pw- } \\
\text { PP_R }\end{array}$ & 5 & PP_R & Ts & Ts $/ 30$ & $\mathrm{Ts} / 0$ & $\mathrm{Pw} / 0$ & $\mathrm{Ts} / 0$ & $\mathrm{Ts} / 30$ \\
\hline $\begin{array}{l}\text { Rs-Pw- } \\
\text { HDPE }\end{array}$ & 5 & HDPE & Rs & Rs/30 & $\mathrm{R} / 0 \mathrm{~s}$ & $\mathrm{Pw} / 0$ & Rs $/ 0$ & Rs $/ 30$ \\
\hline $\begin{array}{l}\text { Ys-Pw- } \\
\text { HDPE }\end{array}$ & 5 & HDPE & Ys & Ys/30 & $\mathrm{Y} / 0 \mathrm{~s}$ & $\mathrm{Pw} / 0$ & Ys/0 & Ys/30 \\
\hline $\begin{array}{l}\text { Ts-Pw- } \\
\text { HDPE }\end{array}$ & 5 & HDPE & Ts & Ts $/ 30$ & Ts $/ 0$ & $\mathrm{Pw} / 0$ & $\mathrm{Ts} / 0$ & $\mathrm{Ts} / 30$ \\
\hline $\begin{array}{l}\text { Rs-Pw- } \\
\text { LDPE }\end{array}$ & 5 & LDPE & Rs & $\mathrm{Rs} / 30$ & $\mathrm{R} / 0 \mathrm{~s}$ & $\mathrm{Pw} / 0$ & Rs $/ 0$ & Rs $/ 30$ \\
\hline $\begin{array}{l}\text { Ys-Pw- } \\
\text { LDPE }\end{array}$ & 5 & LDPE & Ys & Ys/30 & $\mathrm{Y} / 0 \mathrm{~s}$ & $\mathrm{Pw} / 0$ & Ys/0 & $\mathrm{Ys} / 30$ \\
\hline $\begin{array}{l}\text { Ts-Pw- } \\
\text { LDPE }\end{array}$ & 5 & LDPE & Ts & Ts $/ 30$ & $\mathrm{Ts} / 0$ & $\mathrm{Pw} / 0$ & $\mathrm{Ts} / 0$ & $\mathrm{Ts} / 30$ \\
\hline $\begin{array}{l}\text { Rs-Pw- } \\
\text { LDPE }\end{array}$ & 5 & LDPE & Rs & Rs/30 & $\mathrm{R} / 0 \mathrm{~s}$ & $\mathrm{Pw} / 0$ & Rs $/ 0$ & Rs $/ 30$ \\
\hline $\begin{array}{l}\text { Ys-Pw- } \\
\text { LDPE }\end{array}$ & 5 & LDPE & Ys & Ys/30 & $\mathrm{Y} / 0 \mathrm{~s}$ & $\mathrm{Pw} / 0$ & Ys/0 & $\mathrm{Ys} / 30$ \\
\hline $\begin{array}{l}\text { Ts-Pw- } \\
\text { LDPE }\end{array}$ & 5 & LDPE & Ts & Ts $/ 30$ & $\mathrm{Ts} / 0$ & $\mathrm{Pw} / 0$ & $\mathrm{Ts} / 0$ & $\mathrm{Ts} / 30$ \\
\hline $\begin{array}{l}\text { Rs-Pw- } \\
\text { LDPE_RZ }\end{array}$ & 5 & LDPE_RZ & Rs & Rs/30 & $\mathrm{R} / 0 \mathrm{~s}$ & $\mathrm{Pw} / 0$ & Rs $/ 0$ & $\mathrm{Rs} / 30$ \\
\hline $\begin{array}{c}\text { Ys-Pw- } \\
\text { LDPE_RZ }\end{array}$ & 5 & LDPE_RZ & Ys & Ys/30 & $\mathrm{Y} / 0 \mathrm{~s}$ & $\mathrm{Pw} / 0$ & Ys/0 & $\mathrm{Ys} / 30$ \\
\hline $\begin{array}{c}\text { Ts-Pw- } \\
\text { LDPE_RZ }\end{array}$ & 5 & LDPE_RZ & Ts & $\mathrm{Ts} / 30$ & Ts $/ 0$ & $\mathrm{Pw} / 0$ & $\mathrm{Ts} / 0$ & $\mathrm{Ts} / 30$ \\
\hline $\begin{array}{c}\text { Rs-Pw- } \\
\text { LDPE_RR }\end{array}$ & 5 & LDPE_RR & Rs & Rs $/ 30$ & $\mathrm{R} / 0 \mathrm{~s}$ & $\mathrm{Pw} / 0$ & Rs $/ 0$ & Rs $/ 30$ \\
\hline $\begin{array}{c}\text { Ys-Pw- } \\
\text { LDPE_RR }\end{array}$ & 5 & LDPE_RR & Ys & Ys/30 & $\mathrm{Y} / 0 \mathrm{~s}$ & $\mathrm{Pw} / 0$ & $\mathrm{Ys} / 0$ & $\mathrm{Ys} / 30$ \\
\hline $\begin{array}{l}\text { Ts-Pw- } \\
\text { LDPE_RR }\end{array}$ & 5 & LDPE_RR & Ts & Ts $/ 30$ & $\mathrm{Ts} / 0$ & $\mathrm{Pw} / 0$ & Ts $/ 0$ & $\mathrm{Ts} / 30$ \\
\hline Rs-Pw-PS & 5 & PS & Rs & Rs/30 & $\mathrm{R} / 0 \mathrm{~s}$ & $\mathrm{Pw} / 0$ & Rs $/ 0$ & Rs $/ 30$ \\
\hline Ys-Pw-PS & 5 & PS & Ys & Ys/30 & $\mathrm{Y} / 0 \mathrm{~s}$ & $\mathrm{Pw} / 0$ & $\mathrm{Ys} / 0$ & $\mathrm{Ys} / 30$ \\
\hline Ts-Pw-PS & 5 & PS & Ts & Ts $/ 30$ & Ts $/ 0$ & $\mathrm{Pw} / 0$ & $\mathrm{Ts} / 0$ & Ts $/ 30$ \\
\hline
\end{tabular}


Thirty percent of the straw were substituted with the thermoplastics which were added to layers 1 and 5. Regardless of the layer, the particles were glued with pMDI adhesive in the amount of $4 \%$ of adhesive dry weight per dry weight of the lignocellulosic material. The manually formed mat was prepared to produce the boards with the thickness of $15 \mathrm{~mm}$ and the target density of $600 \mathrm{~kg} / \mathrm{m}^{3}$. The unit pressure was $2.5 \mathrm{MPa}$, the temperature of heating plate was $200{ }^{\circ} \mathrm{C}$ and pressing time was $20 \mathrm{~s}$ per mm of the board thickness. Pressing process of the mat was conducted between the metal plates.

After hot pressing the molds with the metal plates were subjected to the cold pressing, where they were left under $1000 \mathrm{~N}$ of load until their temperature was decreased to the range of $80-100^{\circ} \mathrm{C}$. The dropping temperature was registered with $\mathrm{K}$ type thermocouples attached to both the upper and the lower surfaces of the plates. Three molds with a dimensions of $700 \times 450 \mathrm{~mm}^{2}$ were produced for each variant.

\subsection{Board Testing}

After the boards conditioning for seven days at $55 \pm 5 \% \mathrm{RH}$ and $21 \pm 1^{\circ} \mathrm{C}$ the produced panels were tested in terms of following parameters according to the relevant standards:

- $\quad$ bending strength (MOR) and modulus of elasticity (MOE) according to EN 310 [66];

- $\quad$ internal bond (IB) according to EN 319 [67];

- $\quad$ internal bond after the boiling test (V-100) according to EN-1087-1 [68];

- $\quad$ thickness swelling (TS) after $24 \mathrm{~h}$ according to EN 317 [69] and water absorption (WA).

The water resistance and mechanical properties investigations involved from 10 to 16 samples in each variant. The other analysis was conducted in three to five replications.

\subsection{Statistical Analysis}

The results were analyzed using STATISTICA 13.0 package (StatSoft Inc., Tulsa, OK, USA). The performed analysis was based on ANOVA (analysis of variance) and homogeneous groups were distinguished with the use of Tukey's test (HSD). Homogeneous groups are marked with lowercase letters. The results were analyzed on the significance level of $\mathrm{p}=0.05$.

\section{Results and Discussion}

\subsection{Bending Strength and Modulus of Elasticity in Bending of Board Samples}

Figures 2 and 3 show the influence of the board production method on their mechanical properties. The results shown indicate that when a moisture level typical for pMDI-glued boards is used, the lowest MOR and MOE values are observed for the boards made of rape particles. Our previous studies $[23,29]$ indicate that the boards made of rape particles have static bending strength and modulus of elasticity similar to or slightly lower than the boards made of pine chips. The boards made of straw from popular cereals manufactured in the similar conditions are characterized by significantly higher strength and modulus of elasticity than the pine boards [29]. The applied modification, in form of the increased moisture content in the face layers, resulted in a significant increase in bending strength and modulus of elasticity of the rape boards and in bending strength only in the boards made of rye particles.

It can be assumed that the use of very dry particles in the face layers does not negatively affect the quality of the manufactured boards. The increase in moisture content in the intermediate layer possibly compensates for the negative effect of excessively dry layers in direct contact with heating panels. The influence of the kind of straw and the thermoplastic type was analyzed by ANOVA. We decided to present more extensive results for this analysis only for the influence of the applied modifications on MOR. Figure 4 shows the influence of the kind of straw in the face layers and the type of polymer used. Similarly as in control samples, the manufactured rape boards differ significantly from the boards made from triticale or rye straw.

Differences in strength of the triticale and rye boards are statistically significant, contrary to results for the systems without polymers (Figure 2). In our previous studies, 
we also did not find statistically significant differences in strength of the boards made of these straws [29]. In general, all boards containing thermoplastics in their face layers demonstrate lower strength than the control boards. However, in the case of the boards with LDPE in their face layers, this decrease in strength is not statistically significant.

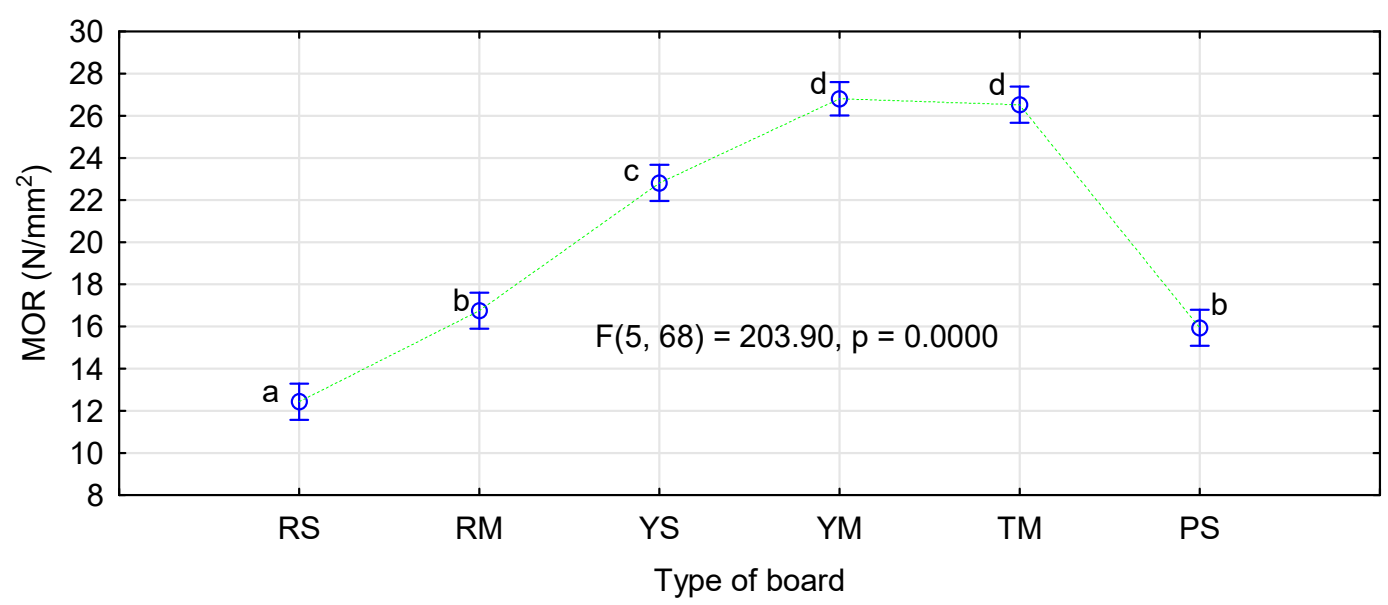

Figure 2. The influence of the board production method and material type on static bending strength: Pl-values for boards containing polymers.

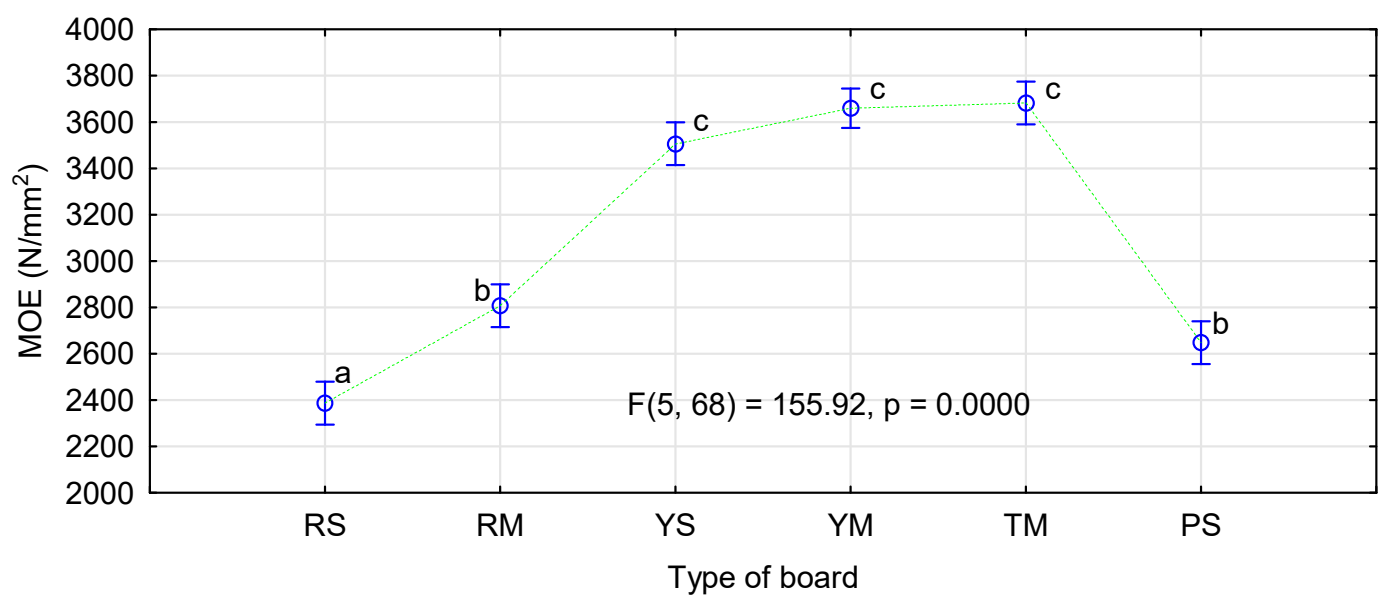

Figure 3. The influence of the board production method and material type on modulus of elasticity.
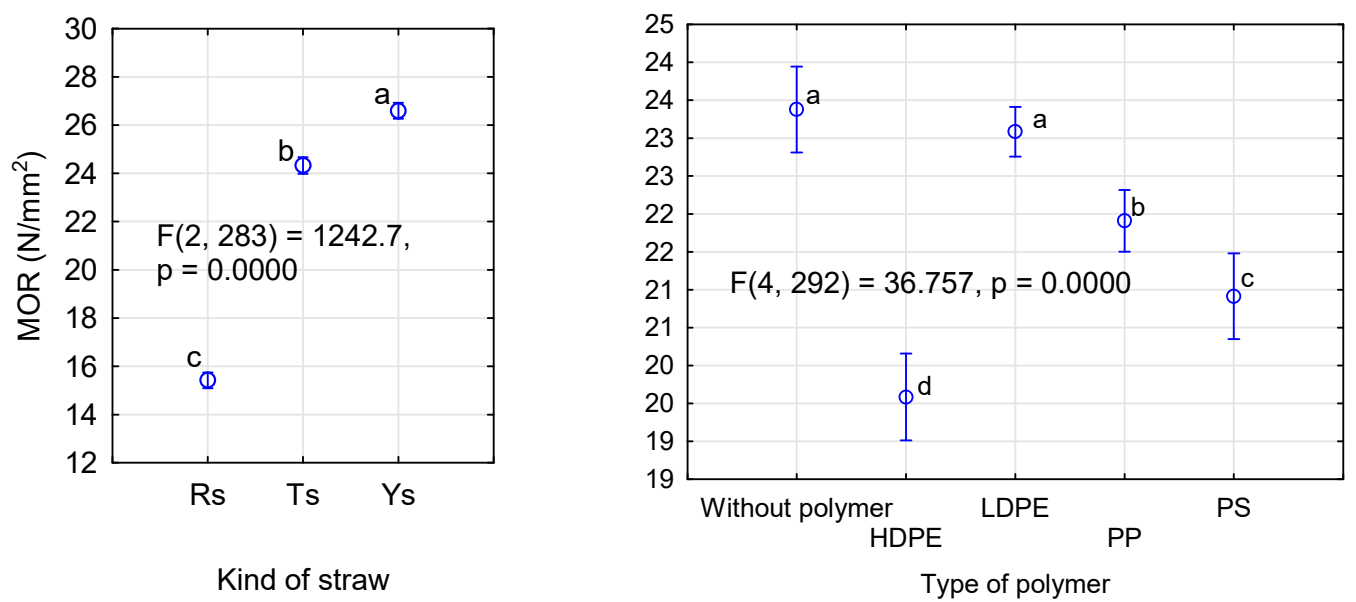

Figure 4. ANOVA for the influence of a straw kind (left) and a polymer type (right) on static bending strength of polymerstraw boards. 
The boards with PP or PS addition are characterized by relatively high strength. For these polymers, mean values of board MOR differ by $1 \mathrm{~N} / \mathrm{mm}^{2}$. The boards with the lowest MOR were obtained when HDPE was used in the face layers. In this case, the strength is still high, slightly below $20 \mathrm{~N} / \mathrm{mm}^{2}$, regardless of the kind of straw used. When a more extensive statistical analysis was conducted, it was found that the strength of the boards containing HDPE did not differ significantly from those containing PS (Figure 5). Furthermore, the boards manufactured with native LDPE are characterized by static bending strength statistically similar to the boards containing polypropylene. What is significant is that the boards manufactured with recycled polymers had a higher static bending strength than those containing the same polymer, but of virgin origin. Although these differences were not statistically significant in the boards with PP, the LDPE boards containing recycled polymer demonstrated improved bending strength.

Figure 6 presents a chart for these interactions. The interaction effect is understood as a simultaneous influence of several factors on a dependent variable in the analysis of variance. In our case, the null hypothesis about interactions must be rejected. This means that the thermoplastic polymers used in the study affected the quality of the manufactured boards always in the same way, regardless of the kind of straw used. Although the straws used in the study differed, especially the rape straw from the rye or triticale straw, none of the polymers changed significantly a trend in strength of the manufactured boards. In all cases, the boards with rye straw achieved the best, and the boards with rape straw the worst results.

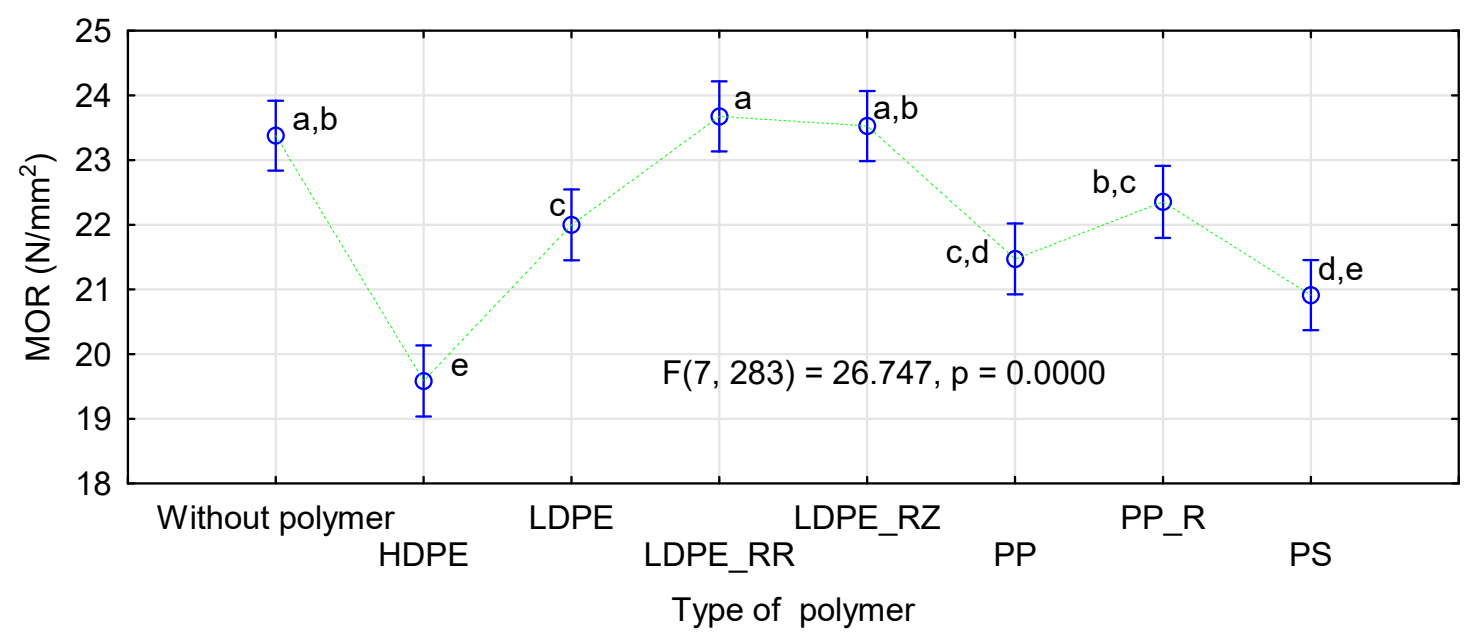

Figure 5. ANOVA evaluating the influence of a polymer type on static bending strength of polymer-straw boards.

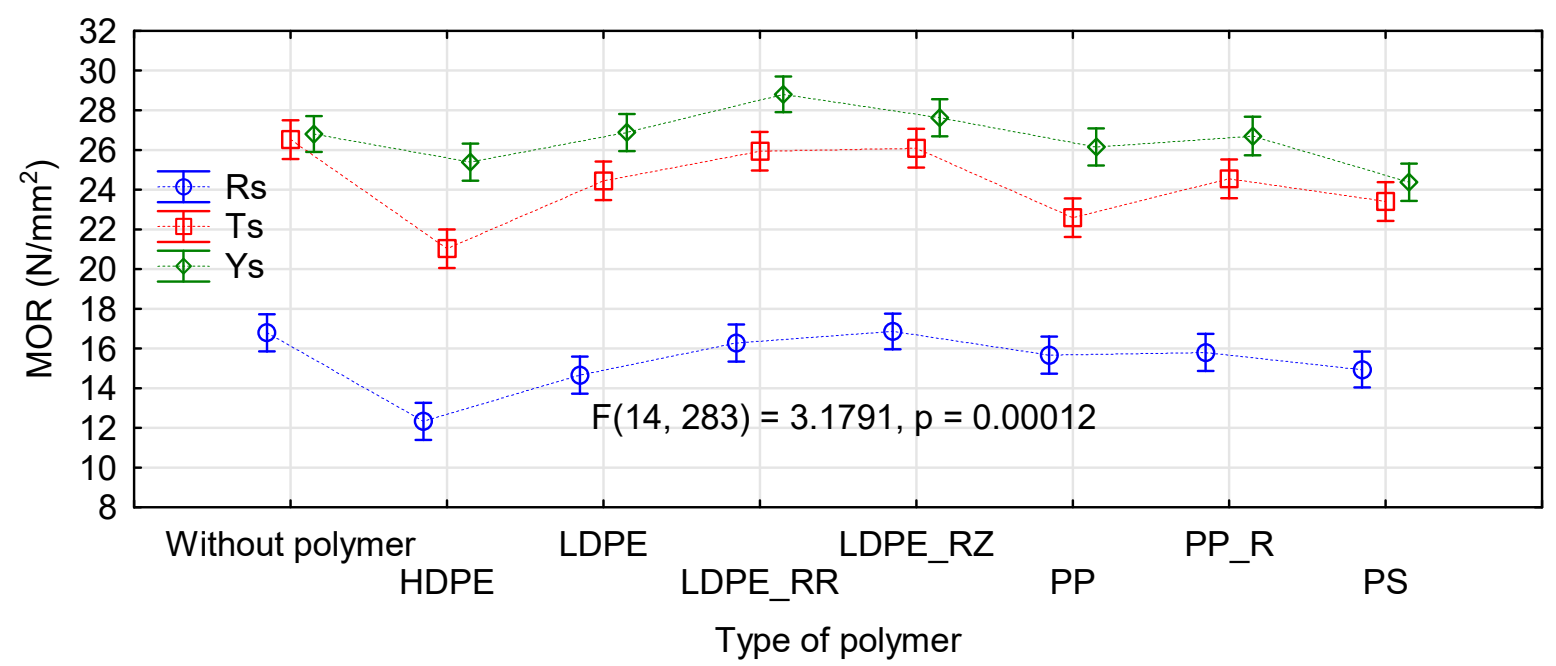

Figure 6. A chart presenting effects of interactions between a straw kind and a polymer type on static bending strength of polymer-straw boards. 
The effect of the straw kind on modulus of elasticity of the straw-polymer boards was similar to its influence on static bending strength (Figure 7). The best results were obtained for rye straw, and the boards with rape straw had the lowest modulus of elasticity. These differences were statistically significant $(F(2,883)=580.55, p=0.0000)$, as confirmed by the Tukey's HSD test.

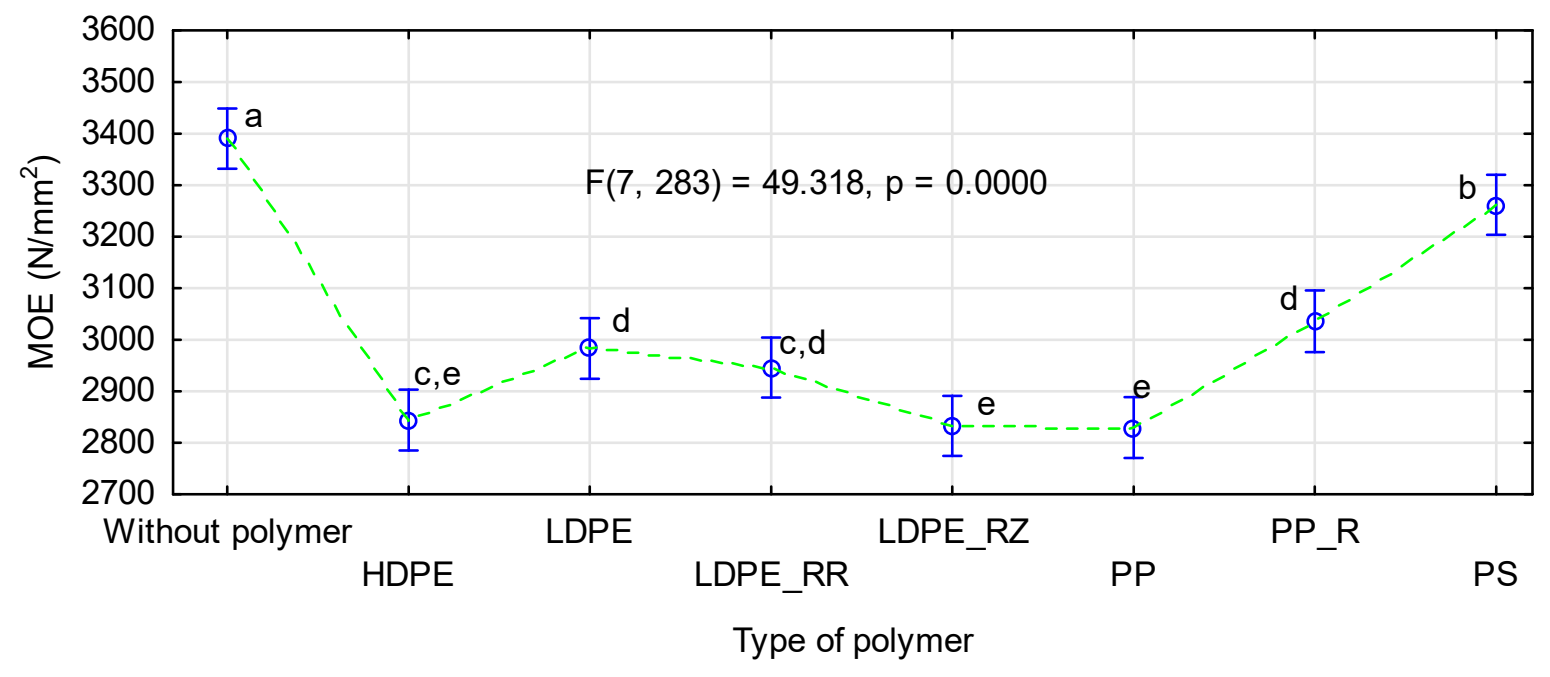

Figure 7. ANOVA evaluating the influence of a polymer type on modulus of elasticity of polymer-straw boards.

Changes in modulus of elasticity caused by the addition of a polymer to the face layers were consistent with changes in modulus of elasticity observed in previous studies [42,52,54,59]. Although, in this case, one of the lowest values of modulus of elasticity was observed also for the boards with HDPE, similarly low values were noted for the boards with LDPE or with any type of polypropylene. The lowest changes in modulus of elasticity (below $4 \%$ ) were found for the boards with polystyrene. In the remaining boards, the decrease in modulus of elasticity ranged from $8 \%$ to $12 \%$.

\subsection{Internal Bond of Board Samples}

In general, internal bond strength evaluates properties of the board core. Usually, except for special boards, in consequence of the pressing process, the density near the core of the board is the lowest, so this zone is destroyed. The boards manufactured in the study had the core of the same material, i.e., pine chips. Therefore, we could expect that the internal bond strength of all boards would be similar in this aspect. However, it turned out that there was a statistically significant difference in the manufactured boards, according to the kind of straw used in the face layers $(F(2,247)=103.23 \mathrm{p}=0.0000)$. The tensile strength perpendicular to the board plane was the highest in the boards containing rape (mean $0.49 \mathrm{~N} / \mathrm{mm}^{2}$ ), followed by rye (mean $0.4 \mathrm{~N} / \mathrm{mm}^{2}$ ), and reaching the lowest value for triticale (mean $0.38 \mathrm{~N} / \mathrm{mm}^{2}$ ). The polymer type also significant influenced the board internal bond strength (Figure 8 ). Internal bond strength of the boards containing HDPE was similar to that of the control boards. Slightly improved values were obtained for PP, especially for the recycled material. Internal bond strength of the boards containing polystyrene and LDPE was comparable and clearly higher than in the control boards. The best results were obtained for the recycled LDPE. In this case, the rape boards were characterized by strength exceeding $0.54 \mathrm{~N} / \mathrm{mm}^{2}$. 


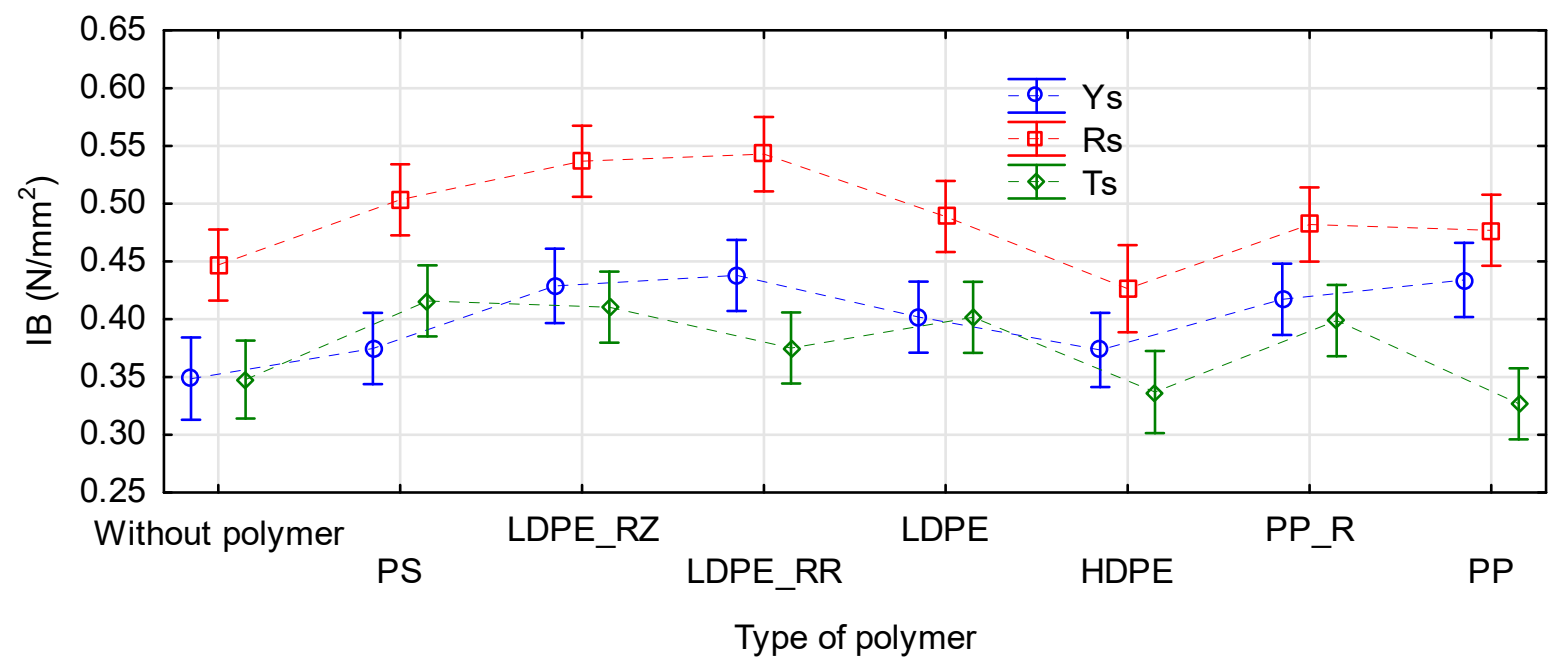

Figure 8. Influence of a straw kind and a polymer type on tensile strength perpendicular to the board plane.

Considering the type of gluing agent used, these boards should meet requirements for type P5 or even P7 construction boards. In terms of mechanical properties, the majority of the analyzed cases met the requirements for boards even of P7 types. Swelling of particle or straw boards during first $24 \mathrm{~h}$ depends, to a large extent, on added agents increasing board hydrophobic properties. Therefore, evaluation of swelling of the manufactured boards against EN 312 [70] requirements was difficult, as no improving agent was used. However, the V100 test was the most important parameter. The manufactured boards did not meet the requirements of this test. The majority of the boards achieved mean values of $0.13 \mathrm{~N} / \mathrm{mm}^{2}$; however, for type P5 boards to pass this test, the 5th percentile value of $0.14 \mathrm{~N} / \mathrm{mm}^{2}$ is required. As it was expected, no influence of the polymer type $(\mathrm{F}(7,264)=1.1786, \mathrm{p}=0.31524)$ on tensile strength perpendicular to the plane after the boiling test was observed.

\subsection{Thickness Swelling and Water Absorption of Board Samples}

Another significant factor of the board quality is their thickness swelling after immersion in water. In this case, the applied modification did not affect observed relations (Figure 9). In general, the boards made of cereal straw showed significantly lower swelling than those made of pine chips. In this case, swelling of the straw boards, both 3- and 5-layer versions, was ca. $15 \%$ lower than of the boards made of pine chips.

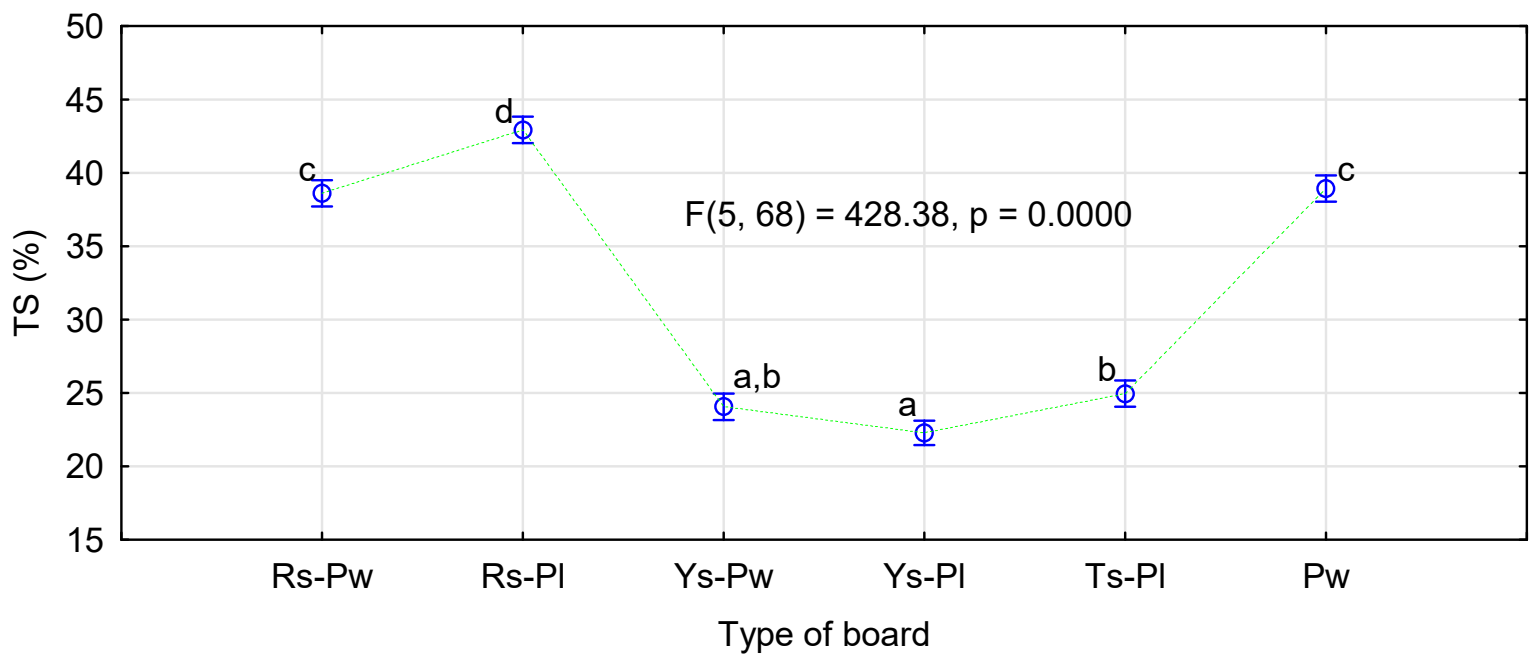

Figure 9. The effect of board production method and type of material on board swelling following $24 \mathrm{~h}$ immersion in water. 
The boards made of rape particles were characterized by swelling similar or slightly higher than those made of pine chips. Usually, boards made of rape particles show slightly lower swelling than pine boards; therefore, the fact that, in this study, the boards of rape particles, especially the 5-layer boards, achieved slightly higher swelling than pine boards was rather unexpected. This difference amounted to $4 \%$ against the rape boards.

To some extent, high swelling of rape boards with a modified moisture content system can be explained by their high absorption capacity (Figure 10). They presented nearly $20 \%$ higher absorption capacity and, therefore, by $4 \%$ greater swelling, did not seem so important.

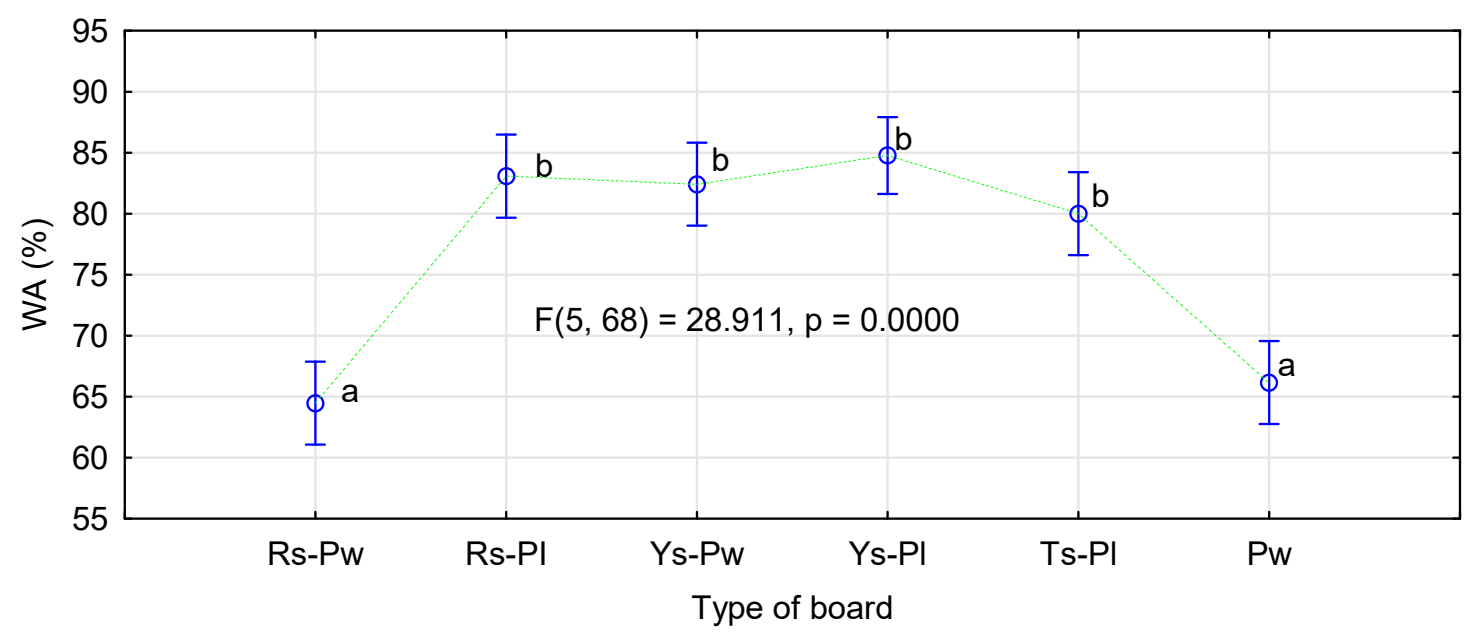

Figure 10. The effect of board production method and type of material on absorption capacity following $24 \mathrm{~h}$ immersion in water.

As in the case of modulus of elasticity, a chart presenting the effect of individual polymers was selected from the conducted ANOVA analyzing swelling of the strawpolymer boards (Figure 11). Additionally, in this case, the boards containing rye had the best results, followed by triticale, and with the worse results for the boards with the rape straw. The boards containing polymers were characterized by a much lower swelling when compared to the boards manufactured without them. Although differences in swelling between individual board types were not large, the statistical analysis showed that the use of recycled polymers was the most advantageous. The lowest and similar swelling values were obtained for the boards with LDPE-RZ, PP_R, and LDPE_RR. Of the boards containing polymers, those containing HDPE achieved the worst results.

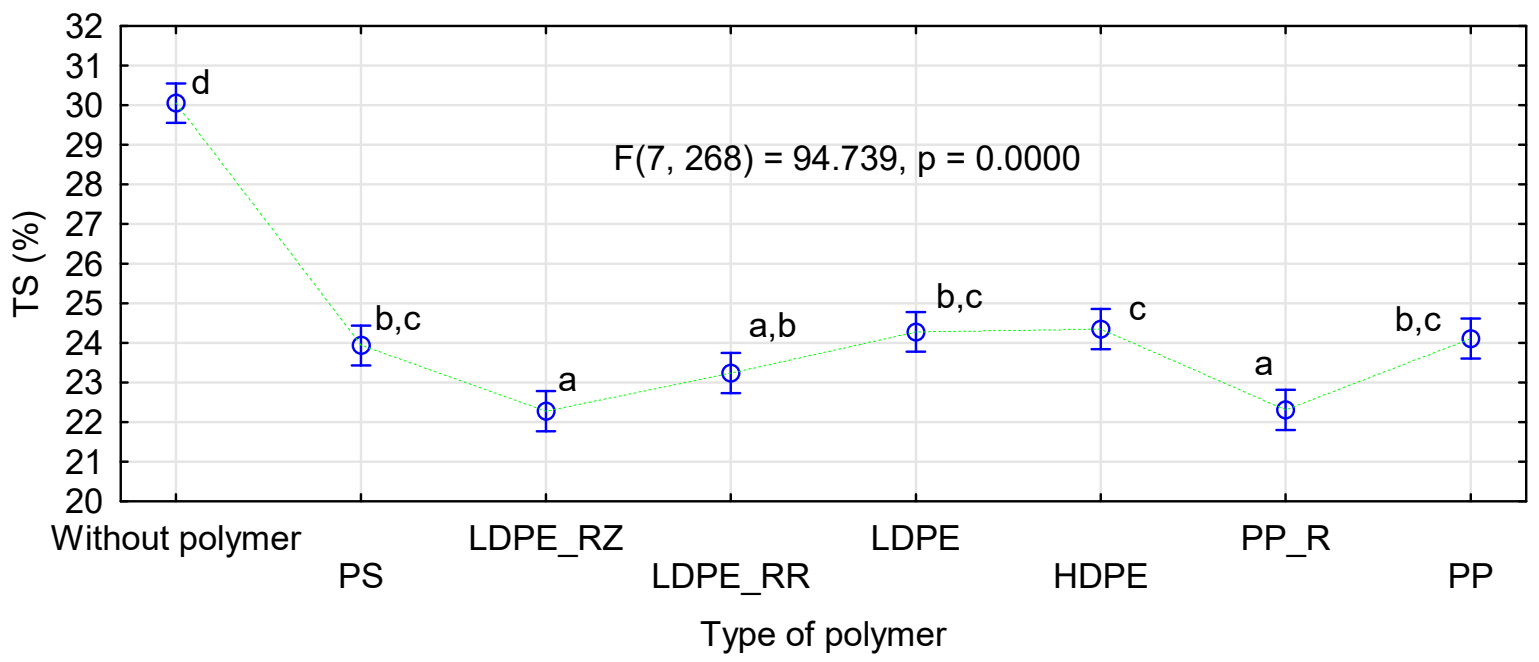

Figure 11. ANOVA evaluating the influence of polymer type on swelling of polymer-straw boards. 
The absorption capacity is usually not specified for furniture and construction boards. However, as these solutions are relatively new, Figure 12 presents a chart of interactions obtained by ANOVA. The result of the analysis itself is less important, as it is consistent with previous analyses concerning mechanical properties. However, the chart shows that the kind of straw had a lower influence on absorption capacity of the manufactured boards. As in previous studies, the boards made of rape straw absorbed much more water than the remaining straws. However, no clear difference in absorption capacity was observed between the boards made of rye and triticale straws.

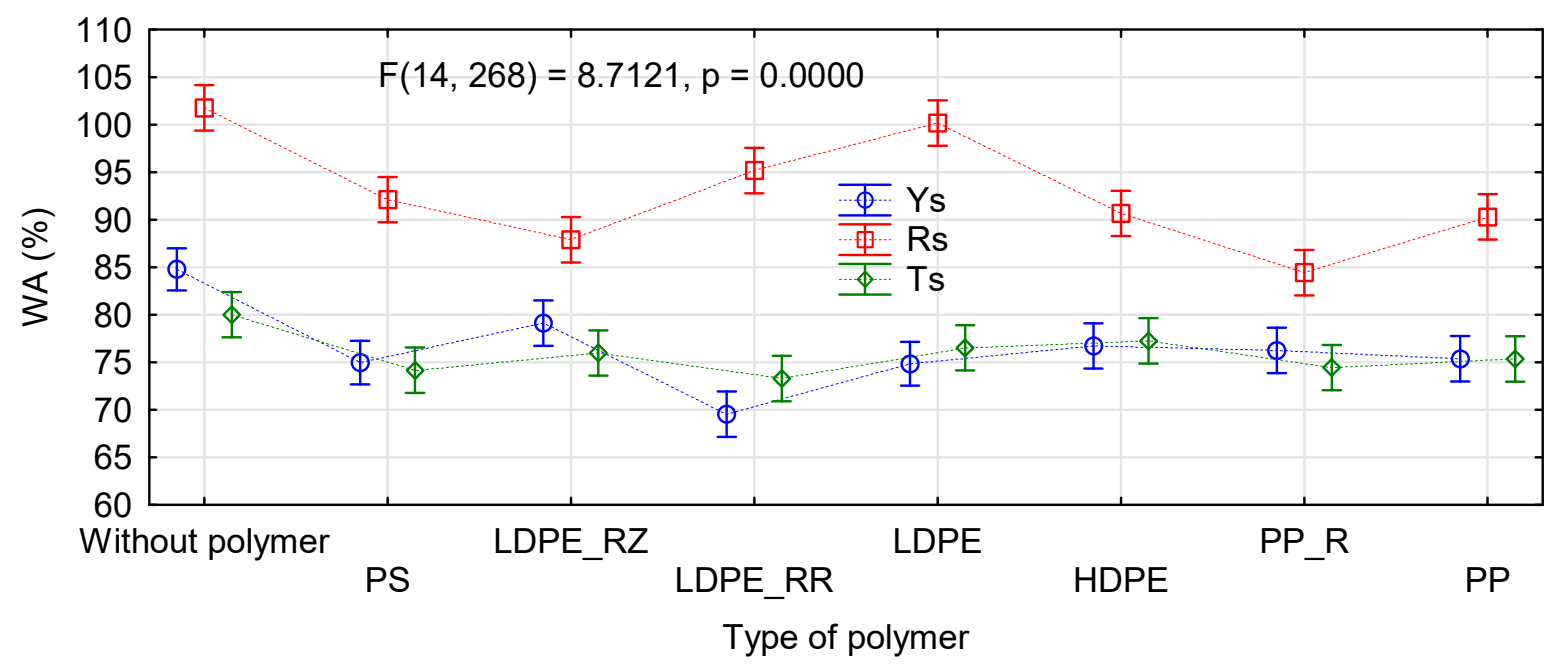

Figure 12. ANOVA evaluating the influence of polymer type on absorption capacity of polymer-straw boards.

\section{Conclusions}

The addition of thermoplastic polymers to board face layers significantly influenced physical and mechanical properties of manufactured boards. On one hand, improved water resistance could be observed, manifested as lower swelling or reduced water absorption capacity, while, on the other, a decrease in bending strength or modulus of elasticity was seen. However, changes in physical and mechanical properties strongly depended both on the kind of straw and the type of polymer used. The most advantageous changes in MOE and MOR were observed for the variant containing rye straw, while better results for tensile strength perpendicular to the board plane was noted with rye straw.

The most advantageous results of modulus of elasticity and bending strength determinations were obtained for the boards containing polystyrene and recycled polymers. Changes in water resistance were achieved when recycled polyethylene or polypropylene were used. Therefore, it can be assumed that recycled polymers more strongly improve hydrophobic properties of the boards, with a smaller deteriorating effect on their mechanical properties. The structure of the straws used, although significantly different from the wood, still allows to produce the boards having good mechanical and physical properties, when they are combined with polymers. Furthermore, cereal straws allowed for better shaping of the structure, so the board bending strength was statistically higher than in boards of wood particles. Therefore, changes more frequently observed in boards containing polymers (significant drop in MOR) were not as high barrier in the case of the straw-polymer boards.

Author Contributions: Conceptualization, R.M., A.B. and P.B.; methodology, R.M. and A.B.; validation, R.M., P.B. and A.B.; investigation, R.M. and A.B.; writing-original draft preparation, R.M., A.B. and P.B.; writing-review and editing, R.M., P.B. and A.B. All authors have read and agreed to the published version of the manuscript.

Funding: This research was funded by the Ministry of Science and Higher Education program "Regional Initiative of Excellence" in the years 2019-2022, Project No.005/RID/2018/19. 
Institutional Review Board Statement: Not applicable.

Informed Consent Statement: Not applicable.

Data Availability Statement: The data presented in this study are available on request from the corresponding author.

Acknowledgments: The authors express their sincere thanks to Maciej Jastrząb and Natalia Brachaczek for his help in performing the research.

Conflicts of Interest: The authors declare no conflict of interest.

\section{References}

1. Geimer, R.L.; Montrey, H.M.; Lehmann, W.F. Effects of Layer Characteristics on the Properties of Three-Layer Particleboards. For. Prod. J. 1975, 25, 19-29.

2. Moriarty, C.J. The Effect of Lab-Made Flakes on Physical and Mechanical Property Variability of Laboratory Flakeboard. For. Prod. J. 2002, 52, 69-73.

3. Mayers, K.L. Impact of Strand Geometry and Orientation on Mechanical Properties of Strand Composites. Master's Thesis, Washington State University, Pullman, WA, USA, December 2001.

4. Barnes, D. An Integrated Model of the Effect of Processing Parameters on the Strength Properties of Oriented Strand Wood Products. For. Prod. J. 2000, 50, 33-42.

5. Barnes, D. A Model of the Effect of Strand Lenght and Strand Thickness on the Strenght Properties of Oriented Wood Composites. For. Prod. J. 2001, 51, 36-46.

6. Chen, S.; Du, C.; Wellwood, R. Analysis of Strand Characteristics and Alignment of Commercial OSB Panels. For. Prod. J. 2008, $58,94-98$.

7. Mirski, R.; Dukarska, D.; Derkowski, A.; Czarnecki, R.; Dziurka, D. By-Products of Sawmill Industry as Raw Materials for Manufacture of Chip-Sawdust Boards. J. Build. Eng. 2020, 32, 101460. [CrossRef]

8. Mirski, R.; Derkowski, A.; Dziurka, D.; Dukarska, D.; Czarnecki, R. Effects of a Chipboard Structure on Its Physical and Mechanical Properties. Materials 2019, 12, 3777. [CrossRef]

9. Mirski, R.; Derkowski, A.; Dziurka, D. Possibility of Using Fine Wood Strands for the Production of p5 Type Building Boards. BioResources 2018, 13, 7188-7196. [CrossRef]

10. Moya, L.; Tze, W.T.Y.; Winandy, J.E. The Effect of Cyclic Relative Humidity Changes on Moisture Content and Thickness Swelling Behavior of Oriented Strandboard. Wood Fiber Sci. 2009, 41, 447-460.

11. Fakhri, H.R.; Semple, K.E.; Smith, G.D. Transverse Permeability of OSB.; Part I. The Effects of Core Fines Content and Mat Density on Transverse Permeability. Wood Fiber Sci. 2006, 38, 450-462.

12. Fakhri, H.R.; Semple, K.E.; Smith, G.D. Transverse Permeability of OSB. Part II. Modeling the Effects of Density and Core Fines Content. Wood Fiber Sci. 2006, 38, 463-473.

13. Han, G.; Wu, Q.; Lu, J.Z. The Influence of Fines Content and Panel Density on Properties of Mixed Hardwood Oriented Strandboard. Wood Fiber Sci. 2007, 39, 2-15.

14. Han, G.; Wu, Q.; Lu, J.Z. Selected Properties of Wood Strand and Oriented Strandboard from Small Diameter Southern Pine Trees. Wood Fiber Sci. 2006, 38, 621-632.

15. Lee, L.; Tahir, P.M. Effects of Fine Particle Content on the Properties of Five-Layered Oriented Strand Board. In Proceedings of the XII World Forestry Congress, Quebec City, Canada, 21-28 September 2003.

16. Mirski, R.; Dziurka, D. Applicability of Strand Substitution in the Core of OSB. BioResources 2011, 6, 3080-3086. [CrossRef]

17. Mirski, R.; Dziurka, D. The Utilization of Chips from Comminuted Wood Waste as a Substitute for Flakes in the Oriented Strand Board Core. For. Prod. J. 2011, 61, 473-478. [CrossRef]

18. Mirski, R.; Dziurka, D.; Derkowski, A. The Effect of Mass Fraction of Chips Designed for Particle Board Production in the Core on Properties Of OSB. Lignocellulose 2012, 1, 22-32.

19. Zhang, Y.; Lu, X.; Pizzi, A.; Delmotte, L. Wheat Straw Particleboard Bonding Improvements by Enzyme Pretreatment. Holz Roh Werkst. 2003, 61, 49-54. [CrossRef]

20. Boquillon, N.; Elbez, G.; Schönfeld, U. Properties of Wheat Straw Particleboards Bonded with Different Types of Resin. J. Wood Sci. 2004, 50, 230-235. [CrossRef]

21. Bekhta, P.; Korkut, S.; Hiziroglu, S. Effect of Pretreatment of Raw Materials on Properties of Particleboards Panels Made from Wheat Straw. BioResources 2013, 8, 4766-4774. [CrossRef]

22. Hafezi, S.M.; Hosseini, K.D. Surface Characteristics and Physical Properties of Wheat Straw Particleboards with UF Resin. J. Indian Acad. Wood Sci. 2014, 11, 168-173. [CrossRef]

23. Dziurka, D.; Mirski, R. Lightweight Boards from Wood and Rape Straw Particles. Drewno 2013, 56, 19-31. [CrossRef]

24. Huang, L.; Xia, P.; Liu, Y.; Fu, Y.; Jiang, Y.; Liu, S.; Wang, X. Production of Biodegradable Boards Using Rape Straw and Analysis of Mechanical Properties. BioResources 2016, 11, 772-785. [CrossRef]

25. Li, X.; Cai, Z.; Winandy, J.E.; Basta, A.H. Selected Properties of Particleboard Panels Manufactured from Rice Straws of Different Geometries. Bioresour. Technol. 2010, 101, 4662-4666. [CrossRef] [PubMed] 
26. Zhang, L.; Hu, Y.C. Novel Lignocellulosic Hybrid Particleboard Composites Made from Rice Straws and Coir Fibers. Mater. Des. 2014, 55, 19-26. [CrossRef]

27. Kurochi, Y.; Sato, M. Effect of Surface Structure, Wax Silica on the Properties of Binderless Board Made from Rice Straw. Ind. Crop. Prod. 2015, 77, 949-953. [CrossRef]

28. Wu, T.; Wang, X.; Kito, K. Effects of Pressures on the Mechanical Properties of Corn Straw Bio-Boards. Eng. Agric. Environ. Food 2015, 8, 123-129. [CrossRef]

29. Mirski, R.; Dziurka, D.; Banaszak, A. Properties of Particleboards Produced from Various Lignocellulosic Particles. BioResources 2018, 3, 7758-7765. [CrossRef]

30. Dukarska, D.; Czarnecki, R.; Dziurka, D.; Mirski, R. Construction Particleboards Made from Rapeseed Straw Glued with Hybrid pMDI/PF Resin. Eur. J. Wood Prod. 2017, 75, 175-184. [CrossRef]

31. Wasylciw, W. Oriented Split Straw Board-A New Era in Building Products; Ecological Building Network: San Rafael, CA, USA, 2001

32. Cheng, W.; Han, G.; Fang, D. Oriented Structural Boards from Split Wheat Straw: Effects of Straw Length, Panel Density, and Resin Content. BioResources 2013, 8, 4497-4504. [CrossRef]

33. Mirski, R.; Dziurka, D.; Czarnecki, R. The Possibility of Replacing Strands in the Core Layer of Oriented Strand Board by Particles from the Stems of Rape (Brassica napus L. var. napus). BioResources 2016, 11, 9273-9279. [CrossRef]

34. Pinto, J.; Paiva, A.; Varum, H.; Costa, A.; Cruz, D.; Pereira, S.; Fernandes, L.; Tavares, P.; Agarwal, J. Corn's Cob as a Potential Ecological Thermal Insulation Material. Energ. Build. 2011, 43, 1985-1990. [CrossRef]

35. Faustino, J.; Pereira, L.; Soares, S.; Cruz, D.; Paiva, P.; Varum, H.; Ferreira, J.; Pinto, J. Impact Sound Insulation Technique Using Corn Cob Particleboard. Constr. Build. Mater. 2012, 37, 153-159. [CrossRef]

36. Pinto, J.; Vieira, B.; Pereira, H.; Jacinto, C.; Vilela, P.; Paiva, A.; Pereira, S.; Cunha, V.; Varum, H. Corn Cob Lightweight Concrete for Non-Structural Applications. Constr. Build. Mater. 2012, 34, 346-351. [CrossRef]

37. Grigoriou, A.H. Straw-Wood Composites Bonded with Various Adhesive Systems. Wood Sci. Technol. 2000, 34, 355-365. [CrossRef]

38. Mo, X.-Q.; Cheng, E.; Wang, D.; Sun, S. Physical Properties of Medium-Density Wheat Straw Particleboard Using Different Adhesives. Ind. Crop. Prod. 2003, 18, 47-53. [CrossRef]

39. Dziurka, D.; Mirski, R. UF-pMDI Hybrid Resin for Waterproof Particleboards Manufactured at a Shortened Pressing Time. Drvna Ind. 2010, 61, 245-249.

40. Mirski, R.; Boruszewski, P.; Trociński, A.; Dziurka, D. The Possibility to Use Long Fibres from Fast Growing Hemp (Cannabis sativa L.) for the Production of Boards for the Building and Furniture Industry. BioResources 2018, 12, 3521-3529. [CrossRef]

41. Available online: http://vestaeco.pl/index.html (accessed on 14 September 2020).

42. Borysiak, S.; Paukszta, D. Mechanical Properties of Lignocellulosic/Polypropylene Composites. Mol. Cryst. Liq. Cryst. 2008, 484, 13-22. [CrossRef]

43. Markiewicz, E.; Paukszta, D.; Borysiak, S. Dielectric Properties of Lignocellulosic Materials-Polypropylene Composites. Mater. Sci. Poland 2019, 27, 581-594.

44. Niska, K.; Sain, M. Wood-Polymer Composites; Woodhead Publishing Limited: Cambridge, UK, 2008.

45. Wolcott, M.P. Formulation and Process Development of Flat Pressed Wood-Polyethylene Composites. For. Prod. J. 2003, 53, 25-32.

46. Ayrilmis, N.; Jarusombuti, S. Flat-Pressed Wood Plastic Composite as an Alternative to Conventional Wood-Based Panels. J. Compos. Mater. 2011, 45, 103-112. [CrossRef]

47. Benthien, J.T.; Thoemen, H. Effects of Raw Materials and Process Parameters on the Physical and Mechanical Properties of Flat Pressed WPC Panels. Compos. Part A Appl. Sci. Manuf. 2012, 43, 570-576. [CrossRef]

48. Schmidt, H.; Benthien, J.; Thoemen, H. Processing and Flexural Properties of Surface Reinforced Flat Pressed WPC Panels. Eur. J. Wood Prod. 2013, 71, 591-597.

49. Lyutyy, P.; Bekhta, P.; Sedliačik, J.; Ortynska, G. Properties of Flat-Pressed Wood-Polymer Composites Made Using Secondary Polyethylene. Acta Fac. Xylologiae Zvolen 2014, 56, 39-50.

50. Bekhta, P.; Lyutyy, P.; Ortynska, G. Effects of Different Kinds of Coating Materials on Flat Pressed WPC Panels. Drvna Ind. 2016, 67, 113-118. [CrossRef]

51. Bekhta, P.; Lyutyy, P.; Ortynska, G. Properties of Veneered Flat Pressed Wood Plastic Composites by One-Step Process Pressing. J. Polym. Environ. 2017, 25, 1288-1295. [CrossRef]

52. Mirski, R.; Dziurka, D.; Banaszak, A. Using Rape Particles in the Production of Polymer and Lignocellulose Boards. BioResources 2019, 14, 6736-6746. [CrossRef]

53. Synowiec, J. Sposób Wytwarzania Kompozytu z Polimerów Termoplastycznych i Cząstek Lignocelulozowych. PL 183478 B1, 1996.

54. Borysiuk, P.; Mamiński, M.; Zado, A. Some Comments on the Manufacturing of Thermoplastic-Bonded Particleboards. Ann. Warsaw Univ. Life Sci. For. Wood Technol. 2009, 68, 50-54.

55. Hague, J.R.B.; Loxton, C.; Quinney, R.; Hobson, N. Assessment of the Suitability of Agri-Based Materials for Panel Products. In Proceedings of the First European Panel Products Symposium, Llandudno, UK, 9-10 October 1997.

56. Papadopoulos, A.N.; Hague, J.B.B. The Potential for Using Flax (Linum usitatissimum L.) Shiv as a Lignocellulosic Raw Material for Particleboard. Ind. Crop. Prod. 2003, 17, 143-147. [CrossRef]

57. Directive 2008/98/Ec of the European Parliament and of the Council of 19 November 2008 on Waste and Repealing Certain Directives. Available online: https:/ / eur-lex.europa.eu (accessed on 14 September 2020). 
58. Chaharmahali, M.; Mirbagheri, J.; Tajvidi, M.; Najafi, S.K.; Mirbagheri, Y. Mechanical and Physical Properties of Wood-Plastic Composite Panels. J. Reinf. Plast. Comp. 2010, 29, 310-319. [CrossRef]

59. Mirski, R.; Dziurka, D.; Bekhta, P. Relationships between Thermoplastic Type and Properties of Polymer-Triticale Boards. Polymers 2019, 11, 1750. [CrossRef] [PubMed]

60. Borysiuk, P. MożLiwośCI Wytwarzania PłYT WIórowo-Polimerowych Z Wykorzystaniem PoużYtkowych Termoplastycznych Tworzyw Sztucznych; Wydawnictwo SGGW: Warsaw, Poland, 2012.

61. Qi, C.; Yadama, V.; Guo, K.; Wolcott, M. Thermal Conductivity of Sorghum and Sorghum-Thermoplastic Composite Panels. Ind. Crop. Prod. 2013, 45, 455-460. [CrossRef]

62. Research Report. Wood Plastic Composites Study-Technologies and UK Market Opportunities; The Waste and Resources Action Programme (WRAP): Banbury, UK, 2003.

63. Dziurka, D.; Mirski, R.; Łęcka, J. The Effect of Pine Particle Moisture Content on Properties of Particleboards Resinated with PMDI. EJPAU 2006, 9, 16.

64. Park, B.D.; Riedl, B.; Hsu, E.W.; Shields, J. Hot-Pressing Process Optimization by Response Surface Methodology. For. Prod. J. 1999, 49, 62-68.

65. Kelly, M.W. Critical Literature Review of Relationships between Processing Parameters and Physical Properties of Particleboard. General Technical Report FPL-10; USDA Forest Service, Forest Products Laboratory: Madison, WI, USA, 1977.

66. EN 310. Wood-Based Panels—Determination of Modulus of Elasticity in Bending and of Bending Strength; European Committee for Standardization: Brussels, Belgium, 1993.

67. EN 319. Particleboards and Fibreboards-Determination of Tensile Strength Perpendicular to the Plane of the Board; European Committee for Standardization: Brussels, Belgium, 1993.

68. EN-1087-1. Particleboards_-Determination of Moisture Resistance—Boil Test; European Committee for Standardization: Brussels, Belgium, 1995.

69. EN 317. Particleboards and Fibreboards. Determination of Swelling in Thickness after Immersion in Water; European Committee for Standardization: Brussels, Belgium, 1993.

70. EN 312. Particleboards_Specifications; European Committee for Standardization: Brussels, Belgium, 2003. 